\title{
EFFECT OF FOLIAR SPRAY WITH BA (Benzyladenine) AND B-9 (Daminozide) ON ESSENTIAL OIL PRODUCTION AND CHEMICAL COMPOSITION OF Majorana hortensis, MOENCH PLANT \\ Hanafy, M. S. \\ Ornamental Hort. Dept. Fac. of Agric., Cairo Univ., Egypt.
}

\begin{abstract}
This research was conducted at the Agriculture Experimental Station, Faculty of Agriculture, Cairo University, Giza in two successive seasons of 2005-2007 and 2006-2008. The aim of this research was to study the effect of foliar spray with BA and B-9 on essential oil production and chemical composition of marjoram plant. The plants were sprayed with BA at the rates of 50, 100 and 150 ppm, while B-9 at the rates of 500, 1000 and $2000 \mathrm{ppm}$ in addition to control treatment which sprayed with distilled water. The obtained results can be summarized as follows:

$\mathrm{BA}$ at the rates of 50,100 and $150 \mathrm{ppm}$ or B-9 at the rates of 500,1000 and $2000 \mathrm{ppm}$ increased all recorded parameters as compared to control treatment with significant differences in most cases during the two seasons. In the first season, the highest value of essential oil percentage was produced with B-9 at $1000 \mathrm{ppm}$, while the highest values of essential oil yield were obtained with BA at $50,150 \mathrm{ppm}$ and with B-9 at 1000 ppm treatments. In the second season the highest values of essential oil percentage and essential oil yield were produced with BA at 50 and 100 ppm, respectively. The major essential oil components were linalyl acetate and terpinen-4-ol. The highest percentage of linalyl acetate was detected in the oil of the plants sprayed with B-9 at 1000 ppm in the two seasons, while in the first season, the highest percentage of terpinen-4-ol was found in oil of the plants sprayed with B-9 at $500 \mathrm{ppm}$ as well as the highest percentage of terpinen-4-ol in the second season was produced from control treatment followed by B-9 at $500 \mathrm{ppm}$. In the first season, the highest values of chlorophyll $a, b$ and carotenoids were produced with BA at $50 \mathrm{ppm}$, B-9 at 2000 and 500 ppm, respectively. While in the second season, the highest values of chlorophyll $a, b$ and carotenoids were obtained from B-9 at 2000 ppm, BA at $150 \mathrm{ppm}$ and BA at $150 \mathrm{ppm}$, respectively. The highest values of total carbohydrates percentage were resulted in B-9 at 2000 ppm in the two seasons. In the first season, the highest total seasonal yield of essential oil was obtained from B-9 at 1000 ppm, while in the second season, the highest value was produced from BA at $100 \mathrm{ppm}$. Generally in combined statistical analysis B-9 at 1000 ppm was the most effective treatment in increasing total seasonal yield of essential oil. The lowest values of all recorded parameters were produced from the control plants in the two seasons. Different cuts as general mean had a significant effect on all recorded parameters in the two seasons. The highest values of essential oil percentage, chlorophyll $a, b$ and carotenoids were produced from the third cut in the two seasons. Also, the highest values of total carbohydrates percentage were produced from the second cut and third cut in the first and second seasons, respectively. The highest values of essential oil yield were obtained from the third cut and fourth cut in the first and second seasons, respectively. The interaction between the growth regulators (BA or B-9) and the cuts increased all recorded parameters as compared with the control in any cut during the two seasons with significant differences in most cases.
\end{abstract}


Hanafy, M. S.

\section{INTRODUCTION}

Majorana hortensis plant belongs to family Lamiaceae (Labiatae) used for oil production and treatment of many diseases. It is a tender bushy perennial plant, native to the Mediterranean region, Egypt and North Africa. Major oil producing countries include France, Tunisia, Morocco, Egypt, Bulgaria,Hungary and Germany (Lawless, 1992). The production of medicinal and aromatic plants is affected by many factors, i.e. genetic information, climatic and edaphic factors as well as agricultural practices. One of these is the application of growth regulators. Foliar spraying with BA on medicinal and aromatic plants showed a clear effect on increasing essential oil production and chemical composition of the plants. The increasing in carbohydrates content by using BA was reported by Hassanein (1985) on Pelargonium graveolens, Mazrou (1992) on Datura innoxia, Eraki (1994) on Hibiscus sabdariffa, Talaat and Youssef (1998 a) on Borago officinalis, Mousa et al. (2001) on Nigella sativa, Youssef (2004) on Pelargonium graveolens and Agamy (2005) on Hibiscus sabdariffa.

The increasing content of chlorophyll $A, B$ and carotenoids by using BA was stated by Menesi et al. (1994) on Tagetes erecta, Zinnia elegans and Celosia argentea, Talaat and Youssef (1998 b) on Hibiscus sabdariffa, Mousa et al. (2001) on Nigella sativa, Abd El-Aziz (2002) on Majorana hortensis and Agamy (2005) on Hibiscus sabdariffa. Also, the increasing in essential oil percentage and essential oil yield was found by Talaat and Youssef (1998 a) on Borago officinalis, Mousa et al. (2001) on Nigella sativa, Abd El-Aziz (2002) on Majorana hortensis and Youssef (2004) on Pelargonium graveolens.

Also, foliar spray with B-9 [daminozide] on medicinal and aromatic plants had a clear effect on increasing the essential oil production and chemical composition of the plants. The increasing in essential oil percentage and essential oil yield by using B-9 was reported by Abou-Zeid (1974) on caraway and fennel, Eid and Rofaeel (1980) on Pelargonium graveolens, ElSharkawy (1981) on Majorana hortensis, Meawad et al. (1984) on Matricaria chamomilla, Mohandass and Sampath (1985) on Pelargonium graveolens, El-Keltawi and Croteau (1986) on Mentha piperita. Also the increasing in carotenoids content by using B-9 stated by El-Khateeb et al. (1991) on Ruta graveolens.

On the other hand Figueiredo et al. (2006) on Cymbopogon citratus found the opposite effect with B-9.

This research aimed to study the effect of foliar spray with benzyladenine (BA) or daminozide (B-9) on essential oil percentage, essential oil yield and some other chemical composition in marjoram (Majorana hortensis, Moench) plant to improve the essential oil productivity and to evaluate the chemical composition.

\section{MATERIALS AND METHODS}

This experiment was carried out in two successive seasons of 20052007 and 2006-2008 at the Agriculture Experimental Station, Faculty of Agriculture, Cairo University, Giza. Soil of the experiment is sandy clay loam 
which contained $24.15 \%$ clay, $1.12 \%$ silt, $47.16 \%$ fine sand, $27.18 \%$ coarse sand, $7.70 \mathrm{pH}$ value, $2.50 \mathrm{EC}$ value, $11.56,12.15,2.35$ and zero $\mathrm{meq} / \mathrm{L}$ from $\mathrm{SO}_{4}^{-}, \mathrm{Cl}^{-}, \mathrm{HCO}_{3}^{-}$and $\mathrm{CO}_{3}^{-}$, respectively, 8.65, 7.13, 10.64 and $1.30 \mathrm{meq} / \mathrm{L}$ from $\mathrm{Na}^{+}, \mathrm{Mg}^{++}, \mathrm{Ca}^{++}$and $\mathrm{K}^{+}$, respectively. Also it contained $30 \% \mathrm{~N}^{+}$and $0.100 \% \mathrm{P}^{+}$.

Marjoram seeds were sown in plastic trays $(40 \times 60 \times 15 \mathrm{~cm})$, which were filled with a mixture of peatmoss: sand (1:1) on October $15^{\text {th }}, 2005$ and 2006 for the first and second seasons, respectively. The seeds were covered with fine soil and irrigated regularly till the seedlings reached about $12 \mathrm{~cm}$ in height. The seedlings were transplanted on December, $25^{\text {th }}$ in both seasons. Only one uniform seedling was left to grow in each pot $(25 \mathrm{~cm}$ diameter).

The plants were sprayed with BA at the rates of 50,100 and 150 ppm, and B-9 at the rates of 500, 1000 and 2000 ppm in addition to control treatment which sprayed with distilled water, the volume of the sprayed solution of BA or B-9 was maintained just to completely covered the plant foliage till drip. The first spray was after 30 days from planting, while the second spray was carried out after 30 days from the first one. After each cut in the two seasons, the plants were sprayed twice, between the first spray and the second one about 30 days. All the plants received equal dose from NPK fertilizer (10 gm/plant) divided into two portions of NPK at the ratio of 20:10:15 after each cut. Seven treatments were carried out and the experimental unit consisted of 10 plants, one plant/pot $(25 \mathrm{~cm}$ diameter). The treatments were replicated three times. The pots were distributed in randomized complete system. Four cuts were carried out during each season at the following dates:

\begin{tabular}{|c|c|c|}
\hline Cut No. & $\begin{array}{c}\text { First season } \\
\mathbf{2 0 0 5}-\mathbf{2 0 0 7}\end{array}$ & $\begin{array}{c}\text { Second season } \\
\mathbf{2 0 0 6}-\mathbf{2 0 0 8}\end{array}$ \\
\hline $\mathbf{1}$ & $12 / 5 / 2006$ & $15 / 5 / 2007$ \\
\hline $\mathbf{2}$ & $30 / 8 / 2006$ & $26 / 8 / 2007$ \\
\hline $\mathbf{3}$ & $20 / 11 / 2006$ & $25 / 11 / 2007$ \\
\hline $\mathbf{4}$ & $5 / 4 / 2007$ & $4 / 4 / 2008$ \\
\hline
\end{tabular}

The following data were recorded after each cut:

1- Essential oil percentage.

2- Essential oil yield (ml/plant/cut).

3- Total seasonal yield of essential oil ( $\mathrm{ml} /$ plant).

4- Essential oil composition

5- Chlorophyll A content( $\mathrm{mg} / \mathrm{gm}$ fresh weight).

6- Chlorophyll B content( $\mathrm{mg} / \mathrm{gm}$ fresh weight).

7- Carotenoids content ( $\mathrm{mg} / \mathrm{gm}$ fresh weight).

8- Total carbohydrates percentage.

The essential oil percentage in the dry leaves and flowering tops was determined according to the British Pharmacopoeia (1963) and it analyzed by GLC according to the method performed by Formacek and Kubeczka (1982). The chlorophylls and carotenoids were determined in fresh leaves according to Saric et al. (1967). The total carbohydrates percentages were determined in the dry leaves and flowering tops according to Herbert et al. (1971).

The statistical analysis of the experiment was split plot in randomized complete blocks design. Data were statistically analyzed using MSTAT-C 
software package according to Freed et al. (1989) and the data were subjected to analysis of variance according to Steel et al. (1997). The parameters of total seasonal yield of essential oil was statistically analyzed in randomized complete blocks design for each season separately and combined analysis of variance was computed for the two seasons in each character.

\section{RESULTS AND DISCUSSION}

\section{1- Essential oil percentage:}

The data in Table (1) showed that, growth regulators treatments had a significant effect on increasing essential oil percentage as compared with the control treatment in the two seasons. In the first season, the highest essential oil percentage (1.95\%) was produced from B-9 at $1000 \mathrm{ppm}$ followed by B- 9 at 2000 ppm which produced $1.79 \%$ then decreased to 1.77 , $1.70,1.65$ and $1.62 \%$ with BA at 50,100 ppm, B-9 at 500 ppm and BA at 150 ppm, respectively. Whereas the lowest essential oil percentage (1.54\%) was produced from control treatment.

There were significant differences between treatments. In the second season, the highest value (1.91\%) was produced from BA at $50 \mathrm{ppm}$ followed by $\mathrm{BA}$ at $100 \mathrm{ppm}$ which gave $1.87 \%$ then decreased to $1.82,1.77,1.77$ and $1.65 \%$ with B-9 at $1000,500,2000 \mathrm{ppm}$ and BA at $150 \mathrm{ppm}$, respectively. While the lowest value (1.58\%) was obtained from control treatment. Regarding the general mean of cuts, in the first season, the highest essential oil percentage $(1.74 \%)$ was produced from the third cut, followed by the second and fourth cut which resulted in 1.71 and $1.71 \%$, respectively then decreased to $1.70 \%$ in the first cut. In the second season there were significant differences between different cuts, the highest value $(1.78 \%)$ was obtained from the third cut while decreased to $1.77,1.76$ and $1.75 \%$ at the fourth, second and first cut, respectively. The interaction between growth regulators treatments and different cuts had a significant effect on essential oil \%.

In the first season, the highest value of $1.96 \%$ was obtained from B-9 at $1000 \mathrm{ppm}$ in each of the third and fourth cuts. Whereas the lowest value $(1.50 \%)$ was produced from control treatment in the third cut. In the second season, the highest value (1.92\%) was obtained from BA at $50 \mathrm{ppm}$ in the first cut, while the lowest value $(1.50 \%)$ was obtained from control treatment in the first cut. In general, it was clear that, all growth regulators concentrations significantly increased the essential oil percentage in the two seasons as compared with the control treatment.

These results were in agreement with those obtained by El-Sharkawy (1981) on Majorana hortensis, who found that B-9 at 1000 and 2000 ppm increased the essential oil percentage and the largest amount of essential oil was produced from B-9 at 1000 ppm. Also, Abd El-Aziz (2002) on Majorana hortensis, reported that essential oil percentage was increased in most cases by using BA at 20 or $40 \mathrm{ppm}$. 
Table (1): Essential oil percentage of sweet marjoram (Majorana hortensis, Moench) as affected by growth regulators.

\begin{tabular}{|c|c|c|c|c|c|c|c|c|c|c|}
\hline \multirow{3}{*}{\begin{tabular}{|l} 
Growth \\
regulators \\
concentration \\
s
\end{tabular}} & \multicolumn{5}{|c|}{ First season (2005-2007) } & \multicolumn{5}{|c|}{ Second season (2006-2008) } \\
\hline & \multicolumn{5}{|c|}{ Cuts } & \multicolumn{5}{|c|}{ Cuts } \\
\hline & 1st & 2 nd & $3^{\text {rd }}$ & $4^{\text {th }}$ & Mean & 1st & $2^{\text {nd }}$ & $3^{\text {rd }}$ & $4^{\text {th }}$ & Mean \\
\hline Control & 1.55 & 1.56 & 1.50 & 1.55 & 1.54 & 1.50 & 1.60 & 1.60 & 1.62 & 1.58 \\
\hline BA 50ppm & 1.72 & 1.80 & 1.81 & 1.75 & 1.77 & 1.92 & 1.88 & 1.90 & 1.93 & 1.91 \\
\hline BA 100ppm & 1.64 & 1.76 & 1.76 & 1.65 & 1.70 & 1.88 & 1.84 & 1.86 & 1.91 & 1.87 \\
\hline BA150ppm & 1.60 & 1.60 & 1.64 & 1.63 & 1.62 & 1.60 & 1.72 & 1.64 & 1.65 & 1.65 \\
\hline B-9 500ppm & 1.63 & 1.64 & 1.68 & 1.64 & 1.65 & 1.75 & 1.76 & 1.79 & 1.76 & 1.77 \\
\hline B-9 1000ppm & 1.95 & 1.92 & 1.96 & 1.96 & 1.95 & 1.84 & 1.80 & 1.85 & 1.80 & 1.82 \\
\hline B-9 2000ppm & 1.80 & 1.72 & 1.84 & 1.79 & 1.79 & 1.76 & 1.75 & 1.80 & 1.75 & 1.77 \\
\hline Mean & 1.70 & 1.71 & 1.74 & 1.71 & & 1.75 & 1.76 & 1.78 & 1.77 & \\
\hline sD & $\begin{array}{l}: \mathrm{Gr} \\
: \mathrm{Cl} \\
: \ln t\end{array}$ & ctio & & & $=0$. & & & & $\begin{array}{l}=c \\
=C \\
=C\end{array}$ & $\begin{array}{l}008 \\
008 \\
016\end{array}$ \\
\hline
\end{tabular}

\section{2- Essential oil yield (ml/plant/cut):}

As shown in Table (2) the growth regulators treatments had a significant effect on increasing essential oil yield as a general mean of treatments when compared with the control treatment. In the first season.

Table (2): Essential oil yield (ml/plant) of sweet marjoram (Majorana hortensis, Moench) as affected by growth regulators.

\begin{tabular}{|c|c|c|c|c|c|c|c|c|c|c|}
\hline \multirow{3}{*}{\begin{tabular}{|c|} 
Growth \\
regulators \\
concentrations
\end{tabular}} & \multirow{2}{*}{\multicolumn{5}{|c|}{$\begin{array}{c}\text { First season (2005-2007) } \\
\text { Cuts }\end{array}$}} & \multicolumn{5}{|c|}{ Second season (2006-2008) } \\
\hline & & & & & & \multicolumn{5}{|c|}{ Cuts } \\
\hline & 1st & 2nd & 3 rd & $4^{\text {th }}$ & Mean & 1st & $2^{\text {nd }}$ & $3 \underline{\text { rd }}$ & $4^{\text {th }}$ & Mean \\
\hline Control & 0.20 & 0.22 & 0.27 & 0.15 & 0.21 & 0.18 & 0.29 & 0.32 & 0.36 & 0.29 \\
\hline BA 50ppm & 0.28 & 0.33 & 0.44 & 0.25 & 0.33 & 0.29 & 0.43 & 0.42 & 0.50 & 0.41 \\
\hline BA 100ppm & 0.30 & 0.28 & 0.36 & 0.19 & 0.28 & 0.32 & 0.42 & 0.46 & 0.53 & 0.43 \\
\hline BA150ppm & 0.28 & 0.30 & 0.43 & 0.29 & 0.33 & 0.26 & 0.39 & 0.42 & 0.44 & 0.38 \\
\hline B-9 500ppm & 0.29 & 0.32 & 0.34 & 0.19 & 0.29 & 0.29 & 0.40 & 0.44 & 0.52 & 0.41 \\
\hline B-9 1000ppm & 0.31 & 0.31 & 0.49 & 0.22 & 0.33 & 0.32 & 0.40 & 0.42 & 0.53 & 0.42 \\
\hline B-9 2000ppm & 0.32 & 0.28 & 0.42 & 0.23 & 0.31 & 0.31 & 0.38 & 0.42 & 0.52 & 0.41 \\
\hline Mean & 0.28 & 0.29 & 0.39 & 0.22 & & 0.28 & 0.39 & 0.41 & 0.49 & \\
\hline 90 & $\begin{array}{l}\text { Grow } \\
\text { Cuts } \\
\text { Inter }\end{array}$ & on & & atn & $\begin{aligned} S & =0 . C \\
& =0 . C \\
& =0 . C\end{aligned}$ & & & & & $\begin{array}{l}.037 \\
.053 \\
.073\end{array}$ \\
\hline
\end{tabular}

While the lowest essential oil yield $(0.21 \mathrm{ml} / \mathrm{plant})$ was produced from control treatment. In the second season the essential oil yield higher than in the first one as a general mean of treatments. The highest value $(0.43$ $\mathrm{ml} /$ plant) was obtained from BA at $100 \mathrm{ppm}$ followed by B-9 at $1000 \mathrm{ppm}$ which produced $0.42 \mathrm{ml} /$ plant then decreased to $0.41,0.41$ and 0.41 with BA at $50 \mathrm{ppm}, \mathrm{B}-9$ at 500 and $2000 \mathrm{ppm}$, respectively. The lowest value $(0.29$ $\mathrm{ml} /$ plant) was obtained from control treatment. Concerning to the general mean of cuts, in the first season, the highest essential oil yield $(0.39 \mathrm{ml} / \mathrm{plant})$ was obtained from the third cut, then decreased to $0.29,0.28$ and 0.22 $\mathrm{ml} /$ plant in the second, first and fourth cut, respectively. In the second season the general mean of cuts higher than in the first one. The highest value $(0.49$ 
$\mathrm{ml} /$ plant) was produced from the fourth cut then decreased to $0.41,0.39$ and $0.28 \mathrm{ml} / \mathrm{plant}$ in the third, second and the first cut, respectively. The interaction between growth regulators treatments and the cuts had a significant effect on essential oil yield. In the first season, the highest value $(0.49 \mathrm{ml} /$ plant) was produced from B-9 at $1000 \mathrm{ppm}$ in the third cut, while the lowest value $(0.15 \mathrm{ml} / \mathrm{plant})$ was obtained from the control treatment in the fourth cut. In the second season the highest values $(0.53$ and $0.53 \mathrm{ml} / \mathrm{plant})$ were produced from both BA at $100 \mathrm{ppm}$ and B-9 at $1000 \mathrm{ppm}$ in the fourth cut, while the lowest value $(0.18 \mathrm{ml} / \mathrm{plant})$ was produced from control treatment in the first cut. In general the growth regulators treatments caused a significant increase in essential oil yield as compared with control treatment in the two seasons. These results were in agreement with those obtained by El-Keltawi and Croteau (1986) who stated that foliar application of B-9 [daminozide\} at $1000 \mathrm{ppm}$ increased essential oil yield of Mentha piperita. Also Mousa et al. (2001) stated that application of BA at 20 ppm increased fixed and volatile oil yields in Nigella sativa plant

3-Total seasonal yield of essential oil ( $\mathrm{ml} /$ plant):

The data in Table (3) showed that, growth regulators treatments had a significant effect on increasing the total seasonal yield of essential oil in the first, second seasons and in combined over seasons as compared with control treatment. In the first season the highest total seasonal yield of essential oil $(1.330 \mathrm{ml} / \mathrm{plant})$ was produced from B-9 at $1000 \mathrm{ppm}$, followed by $B A$ at $150 \mathrm{ppm}$ which gave $(1.300 \mathrm{ml} / \mathrm{plant})$ then decreased to 1.297 , $1.257,1.137$ and $1.137 \mathrm{ml} / \mathrm{plant}$ with BA at $50 \mathrm{ppm}, \mathrm{B}-9$ at $2000,500 \mathrm{ppm}$ and $B A$ at $100 \mathrm{ppm}$, respectively. Whereas the lowest total seasonal yield of essential oil $(0.843 \mathrm{ml} /$ plant) was produced from control treatment. In the second season, the highest value $(1.727 \mathrm{ml} / \mathrm{plant})$ was obtained from BA at $100 \mathrm{ppm}$, followed by B-9 at $1000 \mathrm{ppm}$ which gave $1.677 \mathrm{ml} / \mathrm{plant}$ then decreased to $1.653,1.640,1.623$ and $1.510 \mathrm{ml} /$ plant with B-9 at $500 \mathrm{ppm}, \mathrm{BA}$ at $50 \mathrm{ppm}, \mathrm{B}-9$ at $2000 \mathrm{ppm}$ and $\mathrm{BA}$ at $150 \mathrm{ppm}$, respectively. Whereas the lowest value (1.147 ml/plant) was obtained from control treatment.

Concerning to the combined analysis of total seasonal yield of essential oil, it was cleared that, the highest total seasonal yield of essential oil $(1.504 \mathrm{ml} / \mathrm{plant})$ was resulted in B-9 at $1000 \mathrm{ppm}$ followed by BA at 50 $\mathrm{ppm}$ which gave $1.469 \mathrm{ml} /$ plant then decreased to $1.440,1.432,1.405$ and $1.395 \mathrm{ml} / \mathrm{plant}$ with B-9 at $2000 \mathrm{ppm}, \mathrm{BA}$ at $100,150 \mathrm{ppm}$ and B-9 at 500 $\mathrm{ppm}$, respectively, whereas the lowest value $(0.995 \mathrm{ml} / \mathrm{plant})$ was produced from control treatment.

In general, all growth regulators treatments significantly increased the total seasonal yield of essential oil as compared with control treatment in the first, second seasons and in combined analysis. 
Table (3): Total seasonal yield of essential oil ( $\mathrm{ml} / \mathrm{plant}$ ) of sweet marjoram (Majorana hortensis, Moench) as affected by growth regulators.

\begin{tabular}{|l|c|c|c|}
\hline $\begin{array}{c}\text { Growth regulators } \\
\text { concentrations }\end{array}$ & $\begin{array}{c}\text { First season (2005- } \\
\mathbf{2 0 0 7 )}\end{array}$ & $\begin{array}{c}\text { Second season } \\
\text { (2006-2008) }\end{array}$ & $\begin{array}{c}\text { Combined means } \\
\text { over seasons }\end{array}$ \\
\hline Control & 0.843 & 1.147 & 0.995 \\
\hline BA 50ppm & 1.297 & 1.640 & 1.469 \\
\hline BA 100ppm & 1.137 & 1.727 & 1.432 \\
\hline BA150ppm & 1.300 & 1.510 & 1.405 \\
\hline B-9 500ppm & 1.137 & 1.653 & 1.395 \\
\hline B-9 1000ppm & 1.330 & 1.677 & 1.504 \\
\hline B-9 2000ppm & 1.257 & 1.623 & 1.440 \\
\hline L.S.D at 0.05 & $\mathbf{0 . 2 4 5}$ & $\mathbf{0 . 1 2 6}$ & $\mathbf{0 . 1 3 1}$ \\
\hline
\end{tabular}

These results pointed out the importance of growth regulators (BA or B-9) for the increasing the total seasonal yield of essential oil.

These results were in agreement with those obtained by Mahandass and Sampath (1985) on Pelargonium graveolens, who found that the best results of essential oil yield and quality were obtained with alar [daminozide] at $1000 \mathrm{ppm}$. El-Keltawi and Croteau (1986) stated that foliar application of B9 [daminozide] at $100 \mathrm{ppm}$ increased essential oil yield of Mentha piperita. Also, Abd El-Aziz (2002) on Majorana hortensis, found that oil percentage and oil yield per plant and per feddan were increased in most cases by using $\mathrm{BA}$ at 20 or $40 \mathrm{ppm}$.

\section{4- Essential oil composition:}

As shown in Table (4) and Figures (1,2 and 3) the main components of marjoram essential oil are linalyl acetate, terpinen-4-ol, $d$ - $\alpha$-terpineol, $p$ cymene, $\alpha$-pinene, camphene and B-pinene. In the first season, the obtained data revealed that, the major component was linalyl acetate having its higher value $(32.01 \%)$ with B-9 at $1000 \mathrm{ppm}$ and this was followed by $31.02 \%$ with B-9 at 500 ppm, while the lowest percentage $(27.11 \%)$ was obtained from BA at $150 \mathrm{ppm}$. The second major component was terpinene-4-ol, the highest percentage from it $(27.87 \%)$ was obtained from control treatment, while the lowest percentage $(19.00 \%)$ was resulted in BA at $150 \mathrm{ppm}$. The two components (linalyl acetate and terpinen-4-ol) consisted together 59.12, 57.91 and $55.51 \%$ with B-9 at the rates of 500, 2000 and 1000 ppm, respectively.

This mean that these two components represented the most effective components on the quality of marjoram essential oil. Concerning to the other essential oil constituents in the first season, the highest percentages of $d$ - $\alpha$-terpineol, $p$-cymene, $\gamma$-terpinene, $B$-pinene, $\alpha$-pinene and camphene $(8.39,5.18,12.25,7.16,2.33$ and $6.47 \%$, respectively) were produced from control treatment except the former from B-9 at $1000 \mathrm{ppm}$ and the latter from BA at $50 \mathrm{ppm}$ while the lowest percentages of $d-\alpha-$ terpineol, $p$-cymene, $\gamma$-terpinene. B-pinene, $\alpha$-pinene and camphene (4.49, $3.12,4.30,3.12,1.30$ and $5.00 \%$, respectively) were produced from control treatment for d-a-terpineol and B-9 at 2000 ppm for the other constituents, respectively. 
Hanafy, M. S.

Table (4): Essential oil constituents (\%) of sweet marjoram (Majorana hortensis, Moench) as affected by growth regulators in the first cut of the two seasons.

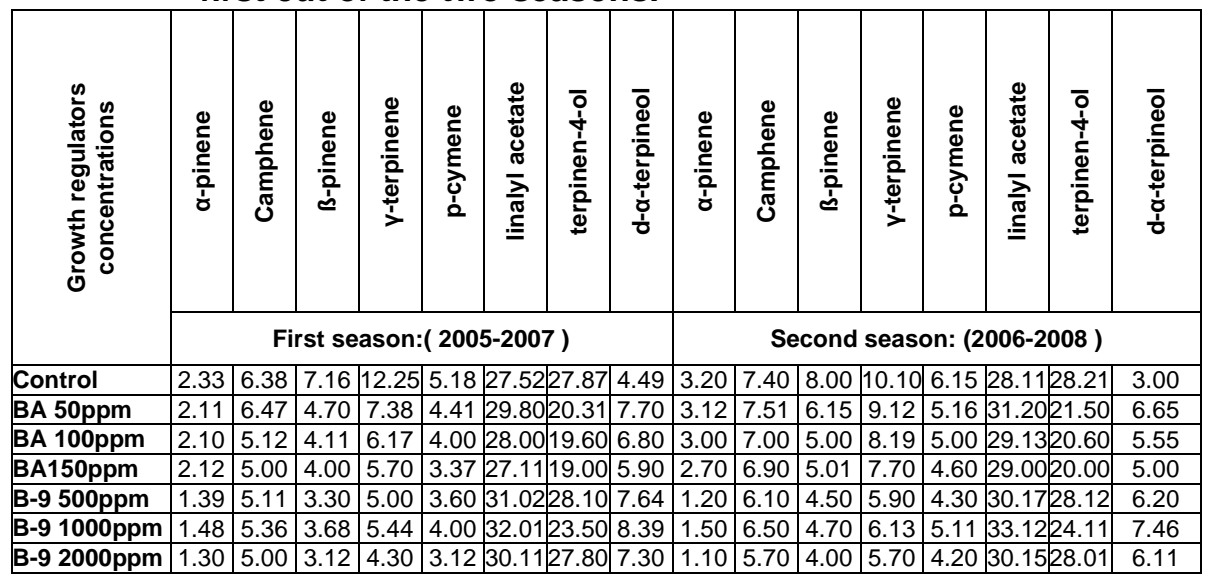

Also in the second season, the data showed that, the major component was linalyl acetate having its higher value (33.12\%) with B-9 at $1000 \mathrm{ppm}$ and this was followed by $31.20 \%$ with BA at $50 \mathrm{ppm}$, while the lowest percentage $(28.11 \%)$ was produced from the control treatment. As well as the second major component was terpinen-4-ol, the highest percentage from it $(28.21 \%)$ was obtained from the control treatment, whereas the lowest percentage from terpinen-4-ol (20.00\%) was produced from BA at $150 \mathrm{ppm}$. The two components (linalyl acetate and terpinen-4-ol) consisted together 58.29, 58.16 and $57.23 \%$ with B-9 at 500, 2000 and 1000 $\mathrm{ppm}$, respectively. This mean that these two components represented the most effective components on the quality of marjoram essential oil.

Regarding the other essential oil constituents in the second season, the highest percentages of $d$ - $\alpha$-terpineol, $p$-cymene, $\gamma$-terpinene, $B$ pinene, $\alpha$-pinene and camphene $(7.46,6.15,10.10,8.00,3.20$ and $7.51 \%$, respectively) were produced from control treatment except the former from $B$ 9 at $1000 \mathrm{ppm}$ and the latter from BA at $50 \mathrm{ppm}$, while the lowest percentages of $d$ - $\alpha$-terpineol, $p$-cymene, $\gamma$-terpinene, $B$-pinene, $\alpha$-pinene and camphene $(3.00,4.20,5.70,4.00,1.10$ and $5.70 \%$, respectively) were produced from control treatment for d-a-terpineol and from B-9 at $2000 \mathrm{ppm}$ for the other constituents, respectively. In general growth regulators treatments affected the constituents of marjoram essential oil. These results were in agreement with those obtained by Meawad et al. (1984) who stated that B-9 [daminozide] at $50-500 \mathrm{ppm}$ were generally the best treatments for increasing essential oil yield and chamazylene percentage in the oil of Matricaria chamomilla plant. Mohandass and Sampath (1985) on Pelargonium graveolens, found that the best results of essential oil yield and quality were obtained with Alar [daminozide] at $1000 \mathrm{ppm}$. Also Youssef (2004) on Pelargonium graveolens, reported that foliar application with BA at 20 and $40 \mathrm{mg} / \mathrm{L}$ induced favourable change in oil yield and altered the relative concentrations of its constituents. 
J. Agric. Sci. Mansoura Univ., 34 (7), July, 2009

ig1

7919 
Hanafy, M. S.

fig2

7920 
J. Agric. Sci. Mansoura Univ., 34 (7), July, 2009

fig3 
Hanafy, M. S.

\section{5- Chlorophyll A (mg/gm F.W.):}

The data in Table (5) showed that, spraying the plants with the growth regulators treatments had a significant effect on increasing chlorophyll A content in the fresh leaves when compared with control treatment as a general mean of treatments. In the first season, the highest chlorophyll $A$ content $(1.02 \mathrm{mg} / \mathrm{gm}$ fresh weight) was obtained from BA at $50 \mathrm{ppm}$, while the lowest value $(0.73 \mathrm{mg} / \mathrm{gm}$ fresh weight) was resulted in control treatment. In the second season the highest content of chlorophyll A $(1.02 \mathrm{mg} / \mathrm{gm}$ fresh weight) was produced from B-9 at $2000 \mathrm{ppm}$, while the lowest value $(0.82$ $\mathrm{mg} / \mathrm{gm}$ fresh weight) was obtained from control treatment. Concerning to the general mean of cuts, it was clear that, in the first season, the highest content of chlorophyll A (1.07 mg/gm fresh weight) was produced from the third cut then followed by second, first and fourth cut, which gave $0.92,0.87$ and 0.84 $\mathrm{mg} / \mathrm{gm}$ fresh weight, respectively.

Table (5): Chlorophyll A content ( $\mathrm{mg} / \mathrm{gm}$ fresh weight) in the leaves of sweet marjoram (Majorana hortensis, Moench) as affected by growth regulators.

\begin{tabular}{|c|c|c|c|c|c|c|c|c|c|c|}
\hline \multirow{3}{*}{$\begin{array}{c}\text { Growth } \\
\text { regulators } \\
\text { concentrations }\end{array}$} & \multicolumn{5}{|c|}{ First season (2005 -2007) } & \multicolumn{5}{|c|}{ Second season (2006 -2008) } \\
\hline & \multicolumn{5}{|c|}{ Cuts } & \multicolumn{5}{|c|}{ Cuts } \\
\hline & 1st & 2nd & 3rd & $4^{\text {th }}$ & Mean & 1st & $2^{\text {nd }}$ & 3 rd & $4^{\text {th }}$ & Mean \\
\hline Control & 0.69 & 0.68 & 0.85 & 0.68 & 0.73 & 0.62 & 0.79 & 0.90 & 0.97 & 0.82 \\
\hline BA 50ppm & 1.05 & 1.28 & 1.05 & 0.70 & 1.02 & 0.64 & 1.05 & 1.11 & 1.00 & 0.95 \\
\hline BA 100ppm & 0.93 & 1.16 & 0.88 & 0.93 & 0.98 & 0.82 & 0.87 & 0.94 & 1.05 & 0.92 \\
\hline BA150ppm & 0.88 & 0.94 & 1.15 & 0.76 & 0.93 & 0.86 & 0.81 & 1.21 & 1.05 & 0.98 \\
\hline B-9 500ppm & 0.88 & 0.70 & 1.13 & 0.93 & 0.91 & 0.82 & 0.87 & 1.20 & 0.99 & 0.97 \\
\hline B-9 1000ppm & 0.82 & 0.81 & 1.16 & 0.93 & 0.93 & 0.76 & 0.81 & 1.27 & 1.05 & 0.97 \\
\hline B-9 2000ppm & 0.82 & 0.87 & 1.25 & 0.93 & 0.97 & 0.64 & 0.99 & 1.32 & 1.11 & 1.02 \\
\hline Mean & 0.87 & 0.92 & 1.07 & 0.84 & & 0.74 & 0.88 & 1.14 & 1.03 & \\
\hline $0 \Omega$ & $\begin{array}{l}\text { Grow } \\
\text { Cuts } \\
\text { Intera }\end{array}$ & & . & & $\begin{array}{l}=0.008 \\
=0.008 \\
=0.016\end{array}$ & & & & & $\begin{array}{l}008 \\
008 \\
147\end{array}$ \\
\hline
\end{tabular}

In the second season, the highest chlorophyll A content $(1.14 \mathrm{mg} / \mathrm{gm}$ fresh weight) was resulted in the third cut, whereas the lowest value from chlorophyll A content $(0.74 \mathrm{mg} / \mathrm{gm}$ fresh weight) was obtained from first cut.

The interaction between growth regulators treatments and the different cuts, had a significant effect on increasing chlorophyll $A$ content as compared with the control in any cuts. In the first season the highest content of chlorophyll A (1.28 mg/gm fresh weight) was obtained from BA at $50 \mathrm{ppm}$ in the second cut, while the lowest values $(0.68$ and $0.68 \mathrm{mg} / \mathrm{gm}$ fresh weight) were produced from control treatment in the second and fourth cuts, respectively. In the second season, the interaction between B-9 at $2000 \mathrm{ppm}$ and the third cut resulted in the highest chlorophyll $A(1.32 \mathrm{mg} / \mathrm{gm}$ fresh weight), while the lowest value $(0.62 \mathrm{mg} / \mathrm{gm}$ fresh weight) was produced from control treatment in the first cut. In general all concentrations of growth regulators treatments caused a significant increase in chlorophyll $A$ content as compared with the control treatment in the two seasons. These results were in agreement with those obtained by Menesi et al. (1994) who showed that chlorophyll A content in leaves of Tagetes erecta, Zinnia elegans and Celosia argentea plants was increased by spraying the plants with BA compared with control. Also Agamy (2005) on Hibiscus sabdariffa reported 
that chlorophyll A, B and carotenoids were significantly increased as a result of application of BA at 100,200 and $400 \mathrm{mg} / \mathrm{L}$.

\section{6- Chlorophyll B (mg/gm F.W.):}

The data in Table (6) showed that, growth regulators treatments had a significant effect on increasing chlorophyll $B$ content as a general mean of treatments in the two seasons as compared with control treatment. In the first season the chlorophyll $B$ content ranged from 0.41 to $0.67 \mathrm{mg} / \mathrm{gm}$ fresh weight. Also the highest chlorophyll B content $(0.67 \mathrm{mg} / \mathrm{gm}$ fresh weight) was obtained from B-9 at $2000 \mathrm{ppm}$, while the lowest value $(0.41 \mathrm{mg} / \mathrm{gm}$ fresh weight) was resulted in control treatment. In the second season the highest chlorophyll B content $(0.71 \mathrm{mg} / \mathrm{gm}$ fresh weight) was produced from BA at $150 \mathrm{ppm}$ then followed by $B-9$ at 2000 which gave $0.70 \mathrm{mg} / \mathrm{gm}$ fresh weight then decreased to $0.69,0.62,0.50$ and $0.48 \mathrm{mg} / \mathrm{gm}$ fresh weight with $\mathrm{B}-9$ at $500 \mathrm{ppm}, \mathrm{B}-9$ at $1000 \mathrm{ppm}, \mathrm{BA}$ at $50 \mathrm{ppm}$ and BA at $100 \mathrm{ppm}$, respectively. Whereas the lowest chlorophyll $B$ content $(0.40 \mathrm{mg} / \mathrm{gm}$ fresh weight) was obtained from control treatment. Regarding the general mean of cuts, it was clear that, in the first season, the highest chlorophyll B content $(0.83 \mathrm{mg} / \mathrm{gm}$ fresh weight) was produced from the third cut then decreased to $0.55,0.53$ and $0.43 \mathrm{mg} / \mathrm{gm}$ fresh weight in the second, fourth and first cut, respectively with significant differences between the all cuts in the second season. The same trend was found as in the first one.

The interaction between growth regulators and different cuts had a significant effect on increasing the chlorophyll B content in the two seasons. In the first season, the highest chlorophyll $B$ content $(1.20 \mathrm{mg} / \mathrm{gm}$ fresh weight) was produced from B-9 at 500 ppm in the third cut then followed by $B-9$ at $2000 \mathrm{ppm}$ which gave $1.18 \mathrm{mg} / \mathrm{gm}$ fresh weight, while the lowest value $(0.36 \mathrm{mg} / \mathrm{gm}$ fresh weight) was resulted in control treatment in the first cut.

Table (6): Chlorophyll B content ( $\mathrm{mg} / \mathrm{gm}$ fresh weight) in the leaves of sweet marjoram (Majorana hortensis, Moench) as affected by growth regulators.

\begin{tabular}{|c|c|c|c|c|c|c|c|c|c|c|}
\hline \multirow{3}{*}{$\begin{array}{c}\text { Growth } \\
\text { regulators } \\
\text { concentrations }\end{array}$} & \multicolumn{5}{|c|}{ First season (2005-2007) } & \multicolumn{5}{|c|}{ Second season (2006-2008) } \\
\hline & \multicolumn{5}{|c|}{ Cuts } & \multicolumn{5}{|c|}{ Cuts } \\
\hline & 1st & 2nd & 3 rd & $4^{\text {th }}$ & Mean & 1st & 2 nd & 3 rd & $4^{\text {th }}$ & Mean \\
\hline Control & 0.36 & 0.43 & 0.45 & 0.40 & 0.41 & 0.25 & 0.48 & 0.42 & 0.43 & 0.40 \\
\hline BA 50ppm & 0.55 & 0.70 & 0.50 & 0.45 & 0.55 & 0.35 & 0.68 & 0.52 & 0.44 & 0.50 \\
\hline BA 100ppm & 0.61 & 0.76 & 0.47 & 0.61 & 0.61 & 0.40 & 0.50 & 0.47 & 0.55 & 0.48 \\
\hline BA150ppm & 0.37 & 0.47 & 0.99 & 0.43 & 0.57 & 0.77 & 0.53 & 1.00 & 0.55 & 0.71 \\
\hline B-9 500ppm & 0.37 & 0.45 & 1.20 & 0.61 & 0.66 & 0.40 & 0.50 & 1.26 & 0.58 & 0.69 \\
\hline B-9 1000ppm & 0.39 & 0.53 & 1.00 & 0.61 & 0.63 & 0.43 & 0.53 & 0.97 & 0.55 & 0.62 \\
\hline B-9 2000ppm & 0.39 & 0.50 & 1.18 & 0.61 & 0.67 & 0.35 & 0.58 & 1.21 & 0.65 & 0.70 \\
\hline Mean & 0.43 & 0.55 & 0.83 & 0.53 & & 0.42 & 0.54 & 0.84 & 0.54 & \\
\hline \multicolumn{5}{|c|}{$\begin{aligned} \text { L.S.D at } 0.05 \text { for }: \text { Growth regulators treatments } \\
\text { : Cuts } \\
\text { : Interaction }\end{aligned}$} & $\begin{array}{l}=0.008 \\
=0.008 \\
=0.005\end{array}$ & & & & \multicolumn{2}{|c|}{$\begin{array}{l}=0.008 \\
=0.008 \\
=0.016\end{array}$} \\
\hline
\end{tabular}

In the second season, the highest chlorophyll B content $(1.26 \mathrm{mg} / \mathrm{gm}$ fresh weight) was produced from B-9 at 500 ppm in the third cut, while lowest value $(0.25 \mathrm{mg} / \mathrm{gm}$ fresh weight) was obtained from control treatment in the first cut. In general, all growth regulators treatments significantly increased chlorophyll B content as a general mean of treatments in the two seasons. 
These results were in agreement with those obtained by Agamy (2005) on Hibiscus sabdariffa who reported that chlorophyll A, B and carotenoids were significantly increased as a result of application of BA at 100, 200 and 400 $\mathrm{mg} / \mathrm{L}$.

\section{7- Carotenoids content (mg/gm F.W.):}

As shown in Table (7) spraying the plants with $\mathrm{BA}$ at 50,100 and 150 ppm or B-9 at 500, 1000 and 2000 ppm had a significant effect on increasing carotenoids content as a general mean of treatments in the two seasons when compared with control treatment. In the first season, the carotenoids content ranged from 0.45 to $0.73 \mathrm{mg} / \mathrm{gm}$ fresh weight. The former was recorded at control treatment, whereas the latter was found with B-9 at 500 $\mathrm{ppm}$. there were significant differences between each treatment and the other as a general mean of treatments. In the second season, the highest carotenoids content $(0.86 \mathrm{mg} / \mathrm{gm}$ fresh weight) was obtained from BA at 150 $\mathrm{ppm}$, whereas the lowest value $(0.57 \mathrm{mg} / \mathrm{gm}$ fresh weight) was produced from control treatment. These were significant differences between each treatment and the other. Concerning to carotenoids content and general mean of cuts, there were significant differences between each cut and the other in the two seasons. In the first season, the highest carotenoids content $(0.86 \mathrm{mg} / \mathrm{gm}$ fresh weight) was obtained from the third cut then followed by second cut which gave $0.59 \mathrm{mg} / \mathrm{gm}$ fresh weight then decreased to 0.58 and $0.53 \mathrm{mg} / \mathrm{gm}$ fresh weight at fourth cut and first cut, respectively. In the second season, the same trend was found as in the first one.

The interaction between growth regulators treatments and different cuts had a significant effect on increasing carotenoids content as compared with control treatment in each cut. In the first season the highest carotenoids content $(1.12 \mathrm{mg} / \mathrm{gm}$ fresh weight) was obtained from B-9 at $500 \mathrm{ppm}$ in the third cut, whereas the lowest content of carotenoids $(0.34 \mathrm{mg} / \mathrm{gm}$ fresh weight) was resulted in control treatment in the first cut. In the second season the highest carotenoids content $(1.24 \mathrm{mg} / \mathrm{gm}$ fresh weight) was produced from $\mathrm{BA}$ at $50 \mathrm{ppm}$ in the second cut then followed by $1.16 \mathrm{mg} / \mathrm{gm}$ fresh weight with B-9 at $500 \mathrm{ppm}$ in the third cut, whereas the lowest value $(0.39$ $\mathrm{mg} / \mathrm{gm}$ fresh weight) was resulted in control treatment in the first cut.

Table (7): Carotenoids content ( $\mathrm{mg} / \mathrm{gm}$ fresh weight) in the leaves of sweet marjoram (Majorana hortensis, Moench) as affected by growth regulators.

\begin{tabular}{|c|c|c|c|c|c|c|c|c|c|c|}
\hline \multirow{3}{*}{$\begin{array}{c}\text { Growth } \\
\text { regulators } \\
\text { concentrations }\end{array}$} & \multirow{2}{*}{\multicolumn{5}{|c|}{$\begin{array}{c}\text { First season (2005-2007) } \\
\text { Cuts }\end{array}$}} & \multicolumn{5}{|c|}{ Second season (2006-2008) } \\
\hline & & & & & & \multicolumn{5}{|c|}{ Cuts } \\
\hline & 1st & 2nd & $3 \underline{\text { rd }}$ & 4th & Mean & 1st & 2nd & 3 rd & $4^{\text {th }}$ & Mean \\
\hline Control & 0.34 & 0.39 & 0.62 & 0.44 & 0.45 & 0.39 & 0.67 & 0.60 & 0.60 & 0.57 \\
\hline BA 50ppm & 0.59 & 0.70 & 0.74 & 0.54 & 0.64 & 0.44 & 1.24 & 0.77 & 0.64 & 0.77 \\
\hline BA 100ppm & 0.61 & 0.95 & 0.63 & 0.61 & 0.70 & 0.67 & 0.86 & 0.65 & 0.69 & 0.72 \\
\hline BA150ppm & 0.51 & 0.59 & 0.95 & 0.48 & 0.63 & 1.15 & 0.70 & 0.93 & 0.66 & 0.86 \\
\hline B-9 500ppm & 0.60 & 0.40 & 1.12 & 0.79 & 0.73 & 0.76 & 0.69 & 1.16 & 0.64 & 0.81 \\
\hline B-9 1000ppm & 0.53 & 0.55 & 1.00 & 0.67 & 0.69 & 0.51 & 0.75 & 0.98 & 0.66 & 0.73 \\
\hline B-9 2000ppm & 0.56 & 0.57 & 0.98 & 0.53 & 0.66 & 0.41 & 0.96 & 0.97 & 0.64 & 0.75 \\
\hline Mean & 0.53 & 0.59 & 0.86 & 0.58 & & 0.62 & 0.84 & 0.87 & 0.65 & \\
\hline L.S.D a & $\begin{array}{l}\text { : Gro } \\
\text { : Cuts } \\
\text { : Inte }\end{array}$ & $\begin{array}{l}\text { ingul } \\
\text { tion }\end{array}$ & tre & ents & $\begin{array}{l}=0.00 \\
=0.00 \\
=0.00\end{array}$ & & & & & $\begin{array}{l}0.008 \\
0.008 \\
0.016\end{array}$ \\
\hline
\end{tabular}


In general BA or B-9 at different concentrations significantly increased carotenoids content as compared with the control treatment. These results were in agreement with those obtained by El-Khateeb et al. (1991) on Ruta graveolens who found that B-9 treatment at 500 and 1000 ppm had a pronounced effect on increasing carotenoids content. Also Talaat and Youssef (1998 b) found that spraying BA at $40 \mathrm{mg} / \mathrm{L}$ on Hibiscus sabdariffa plants increased chlorophyll $A, B$ and carotenoids $(\mathrm{mg} / \mathrm{gm})$ in the leaves.

\section{8- Total carbohydrates percentage:}

The data in Table (8) showed that, all concentrations of BA or all concentrations of B-9 significantly increased total carbohydrates percentage as compared with control treatment. Also, in most cases the total carbohydrates percentage as a general mean of treatments significantly increased as the concentrations of BA or B-9 increased in the two seasons. In the first season the highest total carbohydrates percentage $(39.77 \%)$ was produced from B-9 at $2000 \mathrm{ppm}$ whereas the lowest value $(30.45 \%)$ was obtained from control treatment. In the second season, the same trend was found as in the first one.

Concerning to the general mean of cuts, it was clear that in the first season the highest total carbohydrates percentage (36.49\%) was resulted in second cut followed by $36.04 \%$ in the third cut then decreased to 35.62 and $35.34 \%$ in the fourth and first cut, respectively. In the second season, the highest total carbohydrates percentage $(36.92 \%)$ was produced in the third cut followed by fourth cut which gave $36.20 \%$ then decreased to 35.56 and $34.31 \%$ in the second and first cuts, respectively. The interaction between growth regulators and the different cuts significantly increased total carbohydrates percentage as compared with the control treatment in the two seasons.

Table (8): Percentage of total carbohydrates in the drug of sweet marjoram (Majorana hortensis, Moench) as affected by growth regulators.

\begin{tabular}{|c|c|c|c|c|c|c|c|c|c|c|}
\hline \multirow{3}{*}{$\begin{array}{c}\text { Growth } \\
\text { regulators } \\
\text { concentrations }\end{array}$} & \multicolumn{5}{|c|}{ First season (2005-2007) } & \multicolumn{5}{|c|}{ Second season (2006-2008) } \\
\hline & \multicolumn{5}{|c|}{ Cuts } & \multicolumn{5}{|c|}{ Cuts } \\
\hline & 1-st & 2 nd & 3 rd & $4^{\text {th }}$ & Mean & 1st & 2 nd & $3 \stackrel{\text { rd }}{\text { rd }}$ & $4^{\text {th }}$ & Mean \\
\hline Control & 29.12 & 30.22 & 32.22 & 30.22 & 30.45 & 30.00 & 32.34 & 34.00 & 32.22 & 32.14 \\
\hline BA 50ppm & 32.34 & 31.98 & 33.40 & 32.26 & 32.50 & 31.96 & 33.40 & 34.38 & 33.00 & 33.19 \\
\hline BA 100ppm & 36.00 & 36.32 & 35.60 & 35.12 & 35.76 & 34.22 & 35.80 & 36.22 & 35.20 & 35.36 \\
\hline BA150ppm & 38.02 & 39.60 & 36.56 & 36.30 & 37.62 & 37.76 & 37.40 & 38.30 & 37.80 & 37.82 \\
\hline B-9 500ppm & 36.20 & 38.00 & 36.30 & 36.24 & 36.69 & 34.00 & 36.00 & 36.32 & 35.98 & 35.58 \\
\hline B-9 1000ppm & 37.32 & 39.30 & 37.80 & 39.00 & 38.36 & 34.24 & 36.20 & 38.24 & 37.90 & 36.65 \\
\hline B-9 2000ppm & 38.40 & 40.02 & 40.42 & 40.22 & 39.77 & 37.98 & 37.80 & 41.00 & 41.30 & 39.52 \\
\hline Mean & 35.34 & 36.49 & 36.04 & 35.62 & & 34.31 & 35.56 & 36.92 & 36.20 & \\
\hline \multicolumn{5}{|c|}{$\begin{aligned} \text { L.S.D at } 0.05 \text { for : } & \text { Growth regulators treatments } \\
& : \text { Cuts } \\
& \text { : Interaction }\end{aligned}$} & $\begin{array}{l}=0.008 \\
=0.000 \\
=0.016\end{array}$ & & & & \multicolumn{2}{|c|}{$\begin{array}{l}=0.0082 \\
=0.0076 \\
=0.0164\end{array}$} \\
\hline
\end{tabular}

In the first season the highest total carbohydrates (40.42\%) was obtained from B-9 at $2000 \mathrm{ppm}$ in the third cut, whereas the lowest value $(29.12 \%)$ was produced from control treatment in the first cut. In the second season, the highest total carbohydrates $(41.30 \%)$ was obtained from B-9 at $2000 \mathrm{ppm}$ in the fourth cut, while the lowest value (30.00\%) was resulted in 
control treatment in the first cut. Generally, growth regulators treatments significantly increased the total carbohydrates percentage. These results were in agreement with those obtained by Agamy (2005) on Hibiscus sabdariffa who reported that total carbohydrates percentage was significantly increased as a result of application of BA at 100, 200 and $400 \mathrm{mg} / \mathrm{L}$.

\section{REFERENCES}

Abd El-Aziz, N.G. (2002): Effect of some growth regulators on Majorana hortensis, Moench plant. Ph.D. Thesis, Fac. Agric., Cairo Univ., Egypt.

Abou-Zeid, E.N. (1974): Increase in volatile oil and chemical composition in the seeds of caraway and fennel plants induced by succinic acid, 2dimethylhydrazide. Biolog. Plantarum, 16:123-126.

Agamy, R.A. (2005): Botanical studies on roselle plants (Hibiscus sabdariffa, L.) as affected by benzyladenine and/or decapitation. Annals of Agric. Sci., Moshtohor,43(2):611-626.

British Pharmacopoeia (1963): The pharmaceutical Press 17 Bloomsbury. Square London, W.C.L.

Eid, M.N. and I.S. Rofaeel (1980): Effect of B-9 and CCC on the growth and essential oil of geranium (Pelargonium graveolens, L.) Research. Bulletin, Fac. of Agric., Ain Shams Univ.; (1238):15pp.

El-Keltawi, N.E. and R. Croteau (1986): Influence of ethephon and daminozide on growth and essential oil content of peppermint and sage. Phytochemistry, 25(6):1285-1288.

El-Khateeb, M.A.; E.M. Badaway and A.E. Nadia Boselah (1991): Effect of some growth regulators on growth, chemical comnposition and essential oil of Ruta graveolens, L. plants. Bull. of the Fac. Agric., Cairo Univ., 42(3):829-848.

El-Sharkawy, F.A.A. (1981): Effect of some hormonal and agricultural treatments on the oil yield and chemical constituents of marjoram plants (Majorana hortensis, Moench). Ph. D. Thesis, Fac. Agric., Ain Shams Univ., Egypt.

Eraki, M.A. (1994): Effect of benzyladenine (BA) application on the growth, fruit yield and some chemical constituents of Hibiscus sabdariffa, L. plants. Minofiya J. Agric. Res., (2):623.-637.

Figueiredo, R.O.; M.E.A. Delachiave and L.C. Ming (2006): Growth regulators in biomass production and essential oil in Cymbopogon citratus (DC.) Stapf, in different seasons. Revista, Brasileira de Plantas Medicinais; 8(3):31-35.

Formacek, V. and K. H. Kubeczka (1982): Essential Oil Analysis by Capillary Gas Chromatography and Carbon-13 MR Spectrometry. Published by John Wiley and Sons USA.

Freed, R.S.; P. Einensmith; S. Gutez; D. Reicosky; V.W. Smail and P. Wolberg (1989): User's Guide to MSTAT-C Analysis of Agronomic Research Experiments Michigan State Univ. East Lansing. USA. 
Hassanein, M.A. (1985): Effect of some growth regulators and potassium fertilizers on growth, yield and essential oil production of geranium plants (Pelargonium graveolens, L.). M.Sc. Thesis, Fac. Agric., Cairo Univ., Egypt.

Herbert, D.; P.J. Philipps and R.E. Strange (1971): Determination of total carbohydrates. Methods in microbiol., 58:209-244.

Lawless, Julia (1992): The Encyclopaedia of Essential Oils. Element Book Ltd. Longmead, Shaflesbury, Dorset. U.K.

Mazrou, M.M. (1992): The growth and tropan alkaloids distribution on the different organs of Datura innoxia, Mill. Plants in relation to benzyladenine (BA) application. Minofiya J. Agric. Res., 17(4):19711983.

Meawad, A.A.; A.E. Awad and A.Afify (1984): The combined effect of N. fertilization and some growth regulators on chamomile plants. Acta. Hort., (144): 123-134.

Menesi, Fardous, A.; M.M. Khalafalla and Y. Kandeel (1994): Effect of some growth regulators and calcium chloride on Tagetes erecta L., Zinnia elegans, L. and Celosia argentea,L. plants. The first Conf. Ornamental Hort. Fac. Agric., Cairo Univ., Egypt, (2):408-425.

Mohandass, S. and V. Sampath (1985): Studies on the regulation of growth and yield in geranium with some hormonal sprays. South, Indian Hort., 33(5):344-346.

Mousa, G.T.; I.H. El-Sallami and E.F. Ali (2001): Response of Nigella sativa, L. to foliar application of gibberellic acid, benzyladenine, iron and zinc. Assiut. J. of Agric., Sci., 32(2):141-156.

Saric, M.; R. Kastrari; R. Curic; T. Cupina and I. Geric (1967): Chlorophyll Determination. Univerzit et u Noveon Sadu. Praktikum iz Pizioloize Biljaka Beograd Haucna Anjiga. PP215.

Steel, R.G.D.; J. H. Torrie and D.A. Dickey (1997): Principles and Procedures of Statistics: Abiometrical approach. 3 rd ed. Mc. Graw-Hill, New York.

Talaat, I.M. and A.A. Youssef (1998 a): Effect of kinetin and benzyladenine on the growth and chemical constituents of Borago officinalis, L. plants. Annals of Agric. Sci. Moshtohor, 36(2):827-837.

Talaat, I.M. and A.A. Youssef (1998 b): Response of roselle plants (Hibiscus sabdariffa, L.) to some growth regulating substances. Egypt. J. Hort. Sci., 22(3):327-338.

Youssef, A.A. (2004): Influence of foliar spray with brassinosteroid and benzyladenine on the growth, yield and chemical composition of Pelargonium graveolens, L. plants. Annals of Agric. Sci., Cairo, 49(1):313-326. 
Hanafy, M. S.

\section{تأثير الرش الورقي بالبنزايل أدينين ( BA ) و الآلار (9 - B (B) على إنتاج الزيت

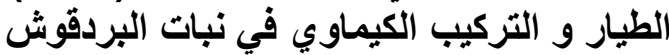

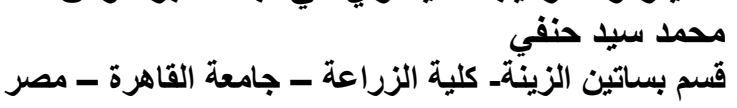

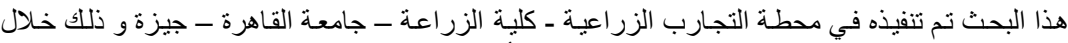

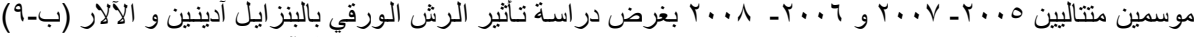

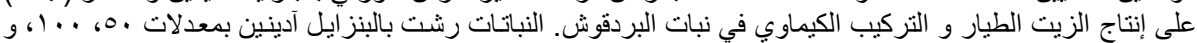

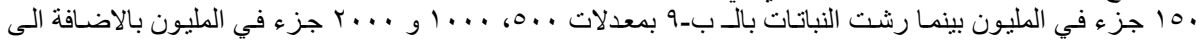

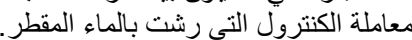

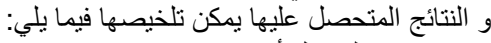

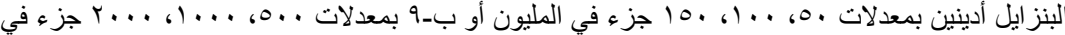

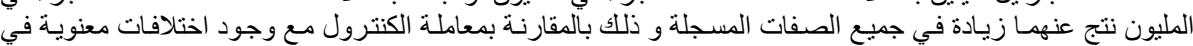

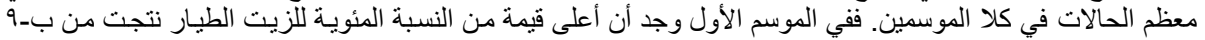

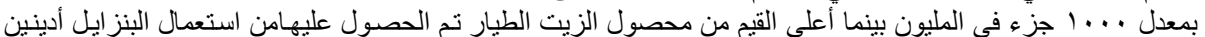

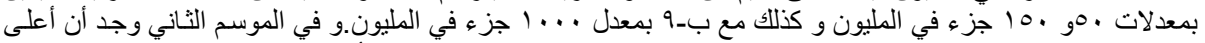

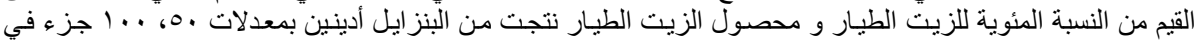

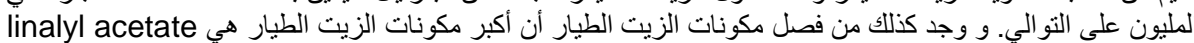

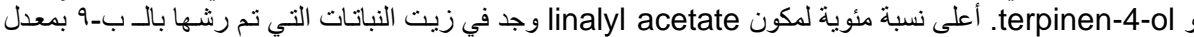

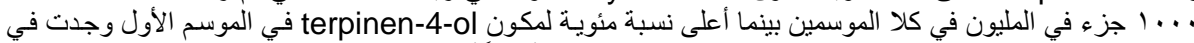

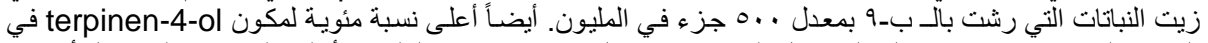

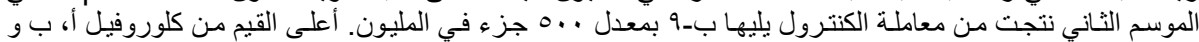

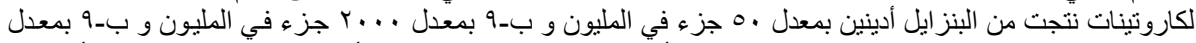

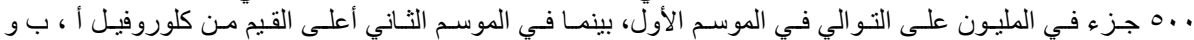

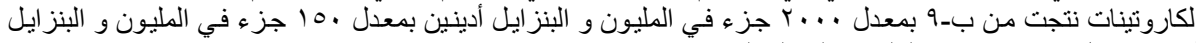

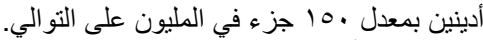

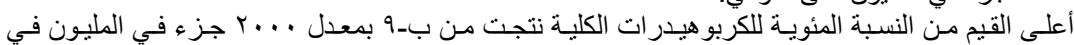

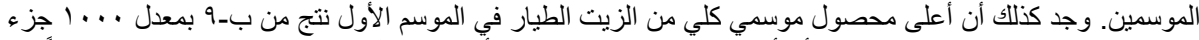

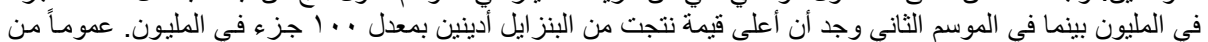

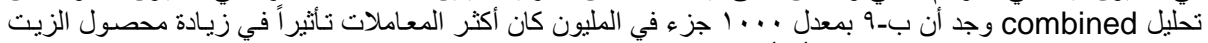

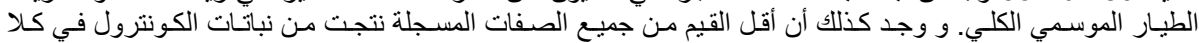

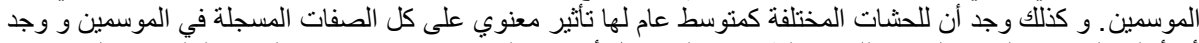

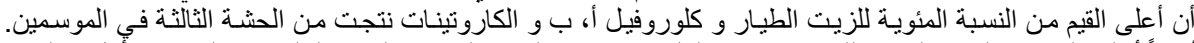

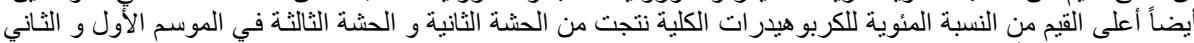

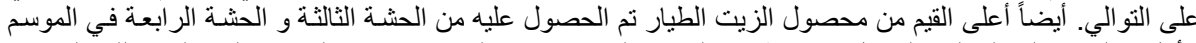

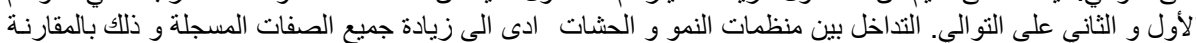
بالكنترول في أي حشة في كلا الموسمين مع وجود فروق معنوية في معظم الحالات النات 